\title{
FAKTOR-FAKTOR YANG MEMPENGARUHI PRILAKU PEMBERIAN ASI EKSKLUSIF DI KELURAHAN TABONA KECAMATAN KOTA TERNATE SELATAN
}

\begin{abstract}
Karima Soamole ${ }^{*}$
Abstract : It is estimated that $80 \%$ of mothers who gave birth were able to produce milk in quantities sufficient for the purposes of the baby in full without any additional food and according to the World Health Organization recommends breastfeeding until the age of 4-6 months baby. Annually, more than 25,000 babies Indonesia and 1.3 million babies around the world can be saved by exclusive breastfeeding in 1999, while according to the 2000 report, the WHO approximately 1.5 million children die because they are not feeding properly, less than $15 \%$ infants worldwide are given for four months of exclusive breastfeeding and complementary feeding is often inappropriate and unsafe. This research is explanatory research because it explains the relationship between independent variables and dependent variable through hypothesis testing. The method used in this study is a survey method with cross sectional study design. The population in this study are all mothers who breastfeed in Puskesmas Kalumata 2012. Knowledge of the highest in the category of knowledge of both 81 (95.3\%) and the behavior of the Exclusive breastfeeding is highest among respondents with a good knowledge of the 55 categories (67.9\%). Respondents' attitudes toward breastfeeding Exclusive showed much respondeng that supports 54 $(63.5 \%)$ and $31(36.5 \%)$ that does not support exclusive breastfeeding her baby. Family Support tehadap respondents in the most exclusive breastfeeding: supporting respondents in exclusive breastfeeding her baby $64(75.3 \%)$ and 21 (24.7\%) who did not support the.
\end{abstract}

Key words : Breastfeeding, Puskesmas Kalumata, complementary feeding.

\section{PENDAHULUAN}

Kesehatan merupakan salah satu aspek dari kehidupan masyarakat mutu hidup, produktifitas tenaga kerja, angka kesakitan dan kematian yang tinggi pada bayi dan anak-anak, menurunnya daya kerja fisik serta terganggunya perkembangan mental adalah akibat langsung atau tidak langsung dari masalah gizi kurang.

Terjadinya rawan gizi pada bayi disebabkan karena selain makanan yang kurang juga karena Air Susu Ibu (ASI) banyak diganti dengan susu botol dengan cara dan jumlah yang tidak memenuhi kebutuhan. ASI sebagai makanan terbaik bagi bayi tidak perlu diragukan lagi, dan tepat untuk pertumbuhan dan perkembangan yang sehat bagi bayi dalam rangka meningkatkan potensi sumber daya manusia oleh sebab itu sejak bayi dilahirkan sampai usia empat bulan makanan yang utama dan pertama adalah Air Susu Ibu (ASI).

Pemberian ASI semaksimal mungkin merupakan kegiatan penting dalam pemeliharaan anak persiapan generasi penerus dimasa depan. Komposisi ASI sangat ideal dan mampu memenuhi kebutuhan bayi setiap hari, karena mengandung zat antibody yang dapat mencegah timbulnya berbagai penyakit. Penggunaan ASI juga mampu meningkatkan keakraban batinnya antara ibu dan anak yang sangat dibutuhkan kemudian hari. ASI tidak memberatkan fungsi traktus digestivus (pencernaan) dan ginjal yang belum berfungsi baik pada bayi yang baru lahir, serta menghasilkan pertumbuhan fisik yang optimum, disamping itu ASI mudah dicerna oleh bayi dan langsung diserap.

Allah SWT memberikan landasan paling hakiki tentang kewajiban menyusui oleh para ibu dalam Firman-Nya: "Para ibu hendaklah menyusukan anak-anaknya selama dua tahun penuh, yaitu bagi yang ingin menyempurnakan penyusuan. Apabila keduanya ingin. menyapih (sebelum dua tahun) dengan kerelaan keduanya dan permusyawaratan, maka tidak ada dosa atas keduanya. Dan jika kamu ingin anakmu disusukan oleh orang lain, maka tidak ada dosa bagimu apabila kamu memberikan pembayaran menurut yang patut. Bertakwalah kamu kepada Allah dan ketahuilah bahwa Allah Maha Melihat apa yang kamu kerjakan" (Al-Baqarah [2]: 233). Hikmah ayat yang terkandung dalam kitab Suci Alqur'an tersebut, setidaknya menekankan bahwa Air Susu Ibu (ASI) sangat penting. Tidak main-main, seorang ibu wajib memberikan ASI sampai anaknya genap usia 2 tahun. Namun, untuk konteks sekarang kelihatanya mengalami degradasi dari berbagai keuntungan dari ASI itu maka pemerintah RI mengeluarkan kebijakan yakni, setiap bayi berhak mendapatkan ASI ekslusif sejak lahir selama enam bulan kecuali atas indikasi medis ( pasal 
128 ayat 1 UU No.36 tahun 2009 tentang Kesehatan, selama pemberian ASI baik pihak keluarga, pemerintah,pemerintah daerah dan masyarakat harus mendukung ibu bayi secara penuh dengan penyediaan waktu dan fasilitas khusus ( pasal 128 ayat 2 UU No. 36 tahun 2009 tentang kesehatan.

Diperkirakan $80 \%$ dari jumlah ibu yang melahirkan ternyata mampu menghasilkan air susu dalam jumlah yang cukup untuk keperluan bayinya secara penuh tanpa makanan tambahan adalah masa yang sangat kritis dalam kehidupan bayi bukan hanya pertumbuhan fisik yang berlangsung dengan cepat, tetapi juga pembentukan psikomotor dan akulturasi terjadi dengan cepat, bahkan ibu yang gizinya kurang baikpun sering dapat menghasilkan ASI yang cukup tanpa makanan tambahan selama tiga bulan pertama.

Menurut WHO (World Health Organization) merekomendasi pemberian ASI saja sampai bayi umur 4-6 bulan, Steven Allen (dalam siaran pers Unicef, 2004) mengatakan bahwa ASI bukanlah sekedar makanan tetapi penyelamat kehidupan. Setiap tahunnya lebih dari 25.000 bayi Indonesia dan 1,3 juta bayi diseluruh dunia dapat diselamatkan dengan pemberian ASI ekslusif tahun 1999, setelah pengalaman selama 9 tahun berdasarkan penelitian yang diadakan WHO, dari 3000 kasus menunjukkan pemberian ASI selama 6 bulan adalah jangka waktu yang paling optimal untuk pemberian ASI ekslusif, sedangkan menurut lapora tahun 2000, Organisasi Kesehatan Dunia (WHO) kurang lebih 1,5 juta anak meninggal kerena pemberian makanan yang tidak benar, kurang dari $15 \%$ bayi diseluruh dunia diberikan ASI ekslusif selama empat bulan dan seringkali pemberian makanan pendamping tidak sesuai dan tidak aman.

Banyak penelitian dan surve yang menyatakan manfaat dan keuntungan dari pemberian ASI ekslusif baik bagi ibu, bagi bayi juga keluarga dan masyarakat, namun ironisnya cakupan ASI ekslusif masih sangat rendah. Menurut Direktorat Jendral Bina Kesehatan Masyarakat (2003) pemberian ASI ekslusif pada bayi sampai usia 4 bulan hanya $55 \%$, dan sampai usia 6 bulan sebesar 39,5\%.

Berdasarkan hasil pemantauan dan laporan dari puskesmas di Wilayah Kota Ternate menunjukkan bahwa dari jumlah 1,876 bayi yang mendapatkan ASI esklusif hanya 749 atau 23\% (Profil Dinkes Kota, 2007).

Berdasarkan data dari Dinas Kesehatan Kota Ternate tahun 2008 di Puskesmas
Sulamadaha jumlah bayi sebanyak 210 bayi, dan yang mendapat ASI eksklusif sebanyak 66 (31\%) bayi, Puskesmas Siko berjumlah 484 bayi, yang mendapat ASI eksklusif sebanyak $293(61 \%)$ bayi, untuk puskesmas Kalumpang jumlah bayi sebanyak 329 bayi dan yang mendapat ASI eksklusif sebanyak 131 (40\%) bayi, puskesmas Kota Ternate terdapat 259 bayi yang mendapat ASI eksklusif sebanyak 121 (41\%) bayi, sedangkan puskesmas Gambesi jumlah bayi sebanyak 63 bayi, yang mendapat ASI eksklusif sebanyak 29 (46\%) bayi. Pada tahun 2012 jumlah bayi di wilayah kerja puskesmas Kalumata sebanyak 1143 bayi, dan yang mendapat ASI eksklusif sebanyak 299 (58\%) bayi.

\section{Rumusan Masalah}

Dengan berbagai keuntungan yang dihasilkan dalam pemberian ASI ekslusif namun pemberianya pada bayi masih minim di kota Ternate hal ini dapat dilihat pada profil Dinkes kota (2007) maka rumusan masalah dalam penelitian ini adalah :

1. Adakah hubungan antara pengetahuan dengan perilaku pemberian ASI ekslusif?

2. Adakah hubungan antara sikap dengan perilaku pemberian ASI ekslusif?

3. Adakah hubungan antara dukungan keluarga dengan pemberian ASI eklusif?.

\section{Tujuan Penelitian}

\section{Tujuan Umum}

Untuk mengetahui faktor-faktor yang mempengaruhi perilaku pemberian ASI eksklusif di kelurahan Tabona ternate tahun 2012.

\section{Tujuan Khusus}

a. Mengidentifikasi karakteristik responden (umur, pendidikan dan pekerjaan)

b. Mengidentifikasi Sikap responden tentang ASI Ekslusif

c. Mengidentifikasi Dukungan keluarga (mertua, orang-tua) dalam pemberian ASI ekslusif.

d. Menganalisis pengaruh karakteristik umur, tingkat pindidikan dan pekerjaan terhadap perilaku pemberian ASI Ekslusif

e. Menganalisis pengaruh Sikap responden terhadap perilaku pembarian ASI ekslusif

f. Menganalisis pengaruh dukungan keluarga (mertua/orang tua) terhadap perilaku pemberian ASI ekslusif 
g. Untuk mengetahui faktor yang paling berpengaruh terhadap perilaku pemberian ASI ekslusif terhadap variabel terikat

\section{METODE PENELITIAN}

Jenis penelitian ini adalah Explanatory Research karena menjelaskan hubungan antara variabel bebas dengan variabel terikat melalui pengujian hipotesis. Metode yang digunakan dalam penelitian ini adalah metode survei dengan desain penelitian cross sectional. Populasi dalam penelitian ini adalah seluruh ibu-ibu yang menyusui yang ada di wilayah kerja Puskesmas Kalumata tahun 2012 adalah

Tabel 1. Distribusi berdasarkan Umur

\begin{tabular}{lcc}
\multicolumn{1}{c}{ Umur Responden } & n & \% \\
\hline Tua & 11 & 12.9 \\
\hline Muda & 74 & 87.1 \\
\hline Jumlah & 85 & 100.0 \\
\hline
\end{tabular}

\section{Pendidikan Responden}

Sebagian besar responden dengan latar belakang pendidikan SMA 27(31.8), responden dengan latar belakang pendidikan tinggi 26(30.6\%), responden

Tabel 2. Distribusi berdasarkan Pendidikan

\begin{tabular}{lcc}
\hline \multicolumn{1}{c}{ Pendidikan Responden } & n & \% \\
\hline sekolah dasar & 13 & 15.3 \\
\hline SMP & 19 & 22.4 \\
\hline SMA & 27 & 31.8 \\
\hline Perguruan Tinggi & 26 & 30.6 \\
\hline Jumlah & 85 & 100.0 \\
\hline
\end{tabular}

\section{Pekerjaan Responden}

Dari tabel 3. diatas menunjukan bahwa sebagian besar responden tidak bekerja

Tabel 3. Distribusi berdasarkan Pekerjaan

\begin{tabular}{lcc}
\hline \multicolumn{1}{c}{ Pekerjaan Responden } & $\mathbf{n}$ & $\mathbf{\%}$ \\
\hline Tidak Bekerja & 44 & 51.8 \\
\hline Bekerja & 41 & 48.2 \\
\hline Jumlah & 85 & 100.0 \\
\hline
\end{tabular}

sebanyak 85 orang. Adapun sampel yang diambil dari penelitian adalah seluruh atau total populasi 85 orang. Penelitian ini telah dilaksanakan pada bulan Juni 2012 yang dilaksanakan di wilayah kerja puskesmas Kalumata Kota Ternate Selatan.

\section{Populasi dan Sampel}

\section{Umur Responden}

Proporsi terbesar adalah responden pada kelompok umur muda 74(87.1\%) dan sisanya adalah responden pada umur tua $11(12.9 \%)$.

dengan latar belakang pendidikan SMP 19(22.4\%), kemudian disusul dengan responden dengan latar belakang pendidikan Sekolah Dasar /SD 13(15.3\%).

$44(51.8 \%)$ dan responden yang bekerja sebesar 41 (48.2\%).

\section{HASIL}

Tabel 4. Pengetahuan responden tentang ASI Ekslusif

\begin{tabular}{lcc}
\hline \multicolumn{1}{c}{ Pengetahuan Responden } & n & \% \\
\hline Baik & 81 & 95.3 \\
\hline Kurang & 4 & 4.7 \\
\hline Jumlah & 85 & 100.0 \\
\hline
\end{tabular}

Responden dengan pengetahuan yang baik

terhadap ASI ekslusif kategori baik sebesar 
81(95.3\%) dan responden yang memiliki

pengetahuan dengan kategori kurang sebesar

Tabel 5. Sikap Responden Terhadap Pemberian ASI Ekslusif

\begin{tabular}{lcc}
\hline Sikap Responden & n & \% \\
\hline Setujuh & 54 & 63.5 \\
\hline Tidak Setujuh & 31 & 36.5 \\
\hline Jumlah & 85 & 100.0 \\
\hline
\end{tabular}

Sebagian besar responden yang setujuh terhadap pemberian ASI Ekslusif 54(63.5) dan yang tidak setujuh sebanyak 31(36.5\%).

Tabel 6. Dukungan Keluarga Terhadap Pemberian ASI Ekslusif

\begin{tabular}{lcc}
\hline Dukungan Keluarga & n & \% \\
\hline Mendukung & 64 & 75.3 \\
\hline Tidak Mendukung & 21 & 24.7 \\
\hline Jumlah & 85 & 100.0 \\
\hline
\end{tabular}

Sebagian besar responden mendapatkan dukungan dari keluarga terhadap pemberian ASI Ekslusif pada bayinya 64(75.3\%) dan

Tabel 7. Perilaku Pemberian ASI Eklusif

\begin{tabular}{lcc}
\hline Perilaku Pemberian ASI Ekslusif & n & \% \\
\hline Memberikan & 58 & 68.2 \\
\hline Tidak Memberikan & 27 & 31.8 \\
\hline Jumlah & 85 & 100.0
\end{tabular}

Dari tabel diatas menunjukan bahwa sebagian besar responden yang memberikan ASI Ekslusif 58(68.2\%) dibandingkan dengan yang tidak memberikan ASI Ekslusif yaitu hanya $27(31.8)$.

\section{Analisa Bivariat}

Analisa bivariat dilakukan untukmenguji hubungan antara variable bebas dengan variabel terikat. Dalam penelitian ini digunakan uji kai quadrat (chi square) untuk mengetahui apakah antara variable bebas dengan variable terikat terdapat hubungan yang signifikan antara statistic atau hanya merupakan kebetulan semata. Nilai kritis $<0.05$ digunakan untuk meolak asumsi bahwa tidak ada hubungan antara variable bebas dan variable terikat pada populasi yang diteliti.

\section{Hubungan Karakteristik Responden Dengan Perilaku Pemberian ASI Ekslusif}

\section{a. Umur responden}

Tabel 8. Hubungan Umur dengan Perilaku Pemberian ASI Ekslusif
Distribusi silang responden menurut umur dengan perilaku pemberian ASI Ekslusif. Dari 11 responden dengan umur kategori muda hanya $5(45.5 \%)$ yang memberikan ASI Ekslusif dan 6(54.5\%) yang tidak memberikan ASI Ekslusif. Dari 74 responden yang berumur kategori tua 53(71.6\%) yang memberikan ASI Eklusif sedangkan 21(28.4\%) yang tidak memberikan ASI Ekslusif. Berdasarkan analisis statistic dengan Chi-Square diperoleh nilai $\mathrm{p}=0.082$. karena nilai $\mathrm{p}>0.05$ maka dapat dinyatakan bahwa tidak terdapat hubungan yang signifikan antara umur dengan pemberia ASI Ekslusif. 


\begin{tabular}{lcccccc}
\hline \multirow{2}{*}{ Umur } & \multicolumn{9}{c}{ Perilaku Pemberian ASI Ekslusif } \\
\cline { 2 - 8 } & \multicolumn{2}{c}{ Memberikan } & \multicolumn{2}{c}{ Tidak Memberikan } & \multicolumn{2}{c}{ Total } \\
\cline { 2 - 8 } & $\mathbf{n}$ & $\boldsymbol{\%}$ & $\mathbf{n}$ & $\boldsymbol{\%}$ & $\mathbf{n}$ & $\boldsymbol{\%}$ \\
\hline Muda & 5 & 45.5 & 6 & 54.5 & 11 & 100 \\
\hline Tua & 53 & 71.6 & 21 & 28.4 & 74 & 100 \\
\hline total & 58 & 68.2 & 27 & 31.8 & 85 & 100 \\
\hline
\end{tabular}

Nilai $\mathrm{p}=0.082$

\section{a. Pendidikan}

Distribusi silang responden menurut pendidikan dengan perilaku pemberian ASI Ekslusif. Dari 13 responden dengan pendidikan SD yang memberikan ASI Ekslusif 10(76.9\%) yang memberikan ASI Ekslusif dan 3(23.1\%) yang tidak memberikan ASI Ekslusif. Dari 19 responden yang berpendidikan SMP $13(68.4 \%)$ yang memberikan ASI Eklusif, dari 27 responden yang memiliki tingkat pendidikan SMA 17(63.0\%) yang memberikan ASI Ekslusif yang tidak memberikan ASI Ekslusif 10(37.0\%) dan dari 26 responden dengan latar belakan pendidikan tinggi 18(69.2\%) yang memberikan ASI Ekslusif pada bayi dan hanya $8(30.8 \%)$ yang tidak memberikan ASI Ekslusif pada bayinya. Berdasarkan analisis statistic dengan Chi-Square diperoleh nilai $\mathrm{p}=0.847$. karena nilai $\mathrm{p}>0.05$ maka dapat dinyatakan bahwa tidak terdapat hubungan yang signifikan antara pendidikan dengan pemberia ASI Ekslusif.

Tabel 9. Hubungan Pendidikan dengan Perilaku Pemberian ASI Ekslusif

\begin{tabular}{lcccccc}
\hline \multirow{2}{*}{ Pendidikan } & \multicolumn{6}{c}{ Perilaku Pemberian ASI Ekslusif } \\
\cline { 2 - 8 } & $\mathbf{n}$ & $\mathbf{\%}$ & $\mathbf{n}$ & $\mathbf{\%}$ & $\mathbf{n}$ & Total \\
\hline Perguruan Tinggi & 18 & 69.2 & 8 & 30.8 & 26 & 100 \\
\hline SMA & 17 & 63.0 & 10 & 37.0 & 27 & 100 \\
\hline SMP & 13 & 68.4 & 6 & 31.6 & 19 & 100 \\
\hline SD & 10 & 76.9 & 3 & 23.1 & 13 & 100 \\
\hline total & 58 & 68.2 & 27 & 31.8 & 85 & 100 \\
\hline
\end{tabular}

Nilai $p=0.847$

\section{c. Pekerjaan}

Distribusi silang responden menurut pekerjaan dengan perilaku pemberian ASI Ekslusif. Dari 41 responden yang bekerja 31(75.6\%) yang memberikan ASI Ekslusif dan $10(24.4 \%)$ yang tidak memberikan ASI Ekslusif. Dari 44 responden yang tidak bekerja 27(61.4\%) yang memberikan ASI
Eklusif dan 17(38.6\%) yang tidak memberikan ASI Ekslusif pada bayinya.

Berdasarkan analisis statistic dengan ChiSquare diperoleh nilai $\mathrm{p}=0.159$ karena nilai p>0.05 maka dapat dinyatakan bahwa tidak terdapat hubungan yang signifikan antara pekerjaan dengan pemberia ASI Ekslusif.

Tabel 10. Hubungan Pekerjaan dengan perilaku Pemberian ASI Ekslusif

\begin{tabular}{lcccccc}
\hline \multirow{2}{*}{ Pekerjaan } & \multicolumn{9}{c}{ Perilaku Pemberian ASI Ekslusif } \\
\cline { 2 - 8 } & \multicolumn{2}{c}{ Memberikan } & \multicolumn{2}{c}{ Tidak Memberikan } & \multicolumn{2}{c}{ Total } \\
\cline { 2 - 8 } & n & \% & n & \% & n & \% \\
\hline Bekerja & 31 & 75.6 & 10 & 24.4 & 41 & 100 \\
\hline Tidak Bekerja & 27 & 61.4 & 17 & 38.6 & 44 & 100 \\
\hline total & 58 & 68.2 & 27 & 31.8 & 85 & 100 \\
\hline Nilai $\mathrm{p}=0.159$ & \multicolumn{7}{c}{} \\
\hline
\end{tabular}

\section{Hubungan Pengetahuan Responden Dengan Perilaku Pemberian ASI Ekslusif}

Dari tabel diatas dapat dilihat bahwa dari 4 responden yang memiliki pengetahuan kategori kurang 3(75.0\%) memberikan ASI
Ekslusif pada bayinya dan 1(25.5\%) yang tidak memberikan ASI Ekslisif pada bayinya. Dari 81 responden yang memiliki pengetahuan tentang ASI Eksludif dengan kategori baik 55(67.9\%)yang memberikan ASI Ekslusif pada 
bayinya dan 26(32.1\%) responden yang tidak memberikan ASI Ekslusif pada bayinya.

Berdasarkan analisis statistic dengan Chi-Square diperoleh nilai $\mathrm{p}=0.766$ karena nilai $\mathrm{p}>0.05$ maka dapat dinyatakan bahwa tidak terdapat hubungan yang signifikan antara pengetahuan responden terhadap ASI Ekslusif dengan perilaku pemberian ASI Ekslusif.

Tabel 10. Hubungan Pengetahuan Responden Dengan Perilaku Pemberian ASI Ekslusif

\begin{tabular}{lcccccc}
\hline \multirow{3}{*}{ Pengetahuan } & \multicolumn{6}{c}{ Perilaku Pemberian ASI Ekslusif } \\
\cline { 2 - 8 } & \multicolumn{2}{c}{ Memberikan } & \multicolumn{2}{c}{ Tidak Memberikan } & \multicolumn{2}{c}{ Total } \\
\cline { 2 - 8 } & $\mathbf{N}$ & $\mathbf{\%}$ & $\mathbf{n}$ & $\mathbf{\%}$ & $\mathbf{n}$ & $\boldsymbol{\%}$ \\
\hline Baik & 55 & 67.9 & 26 & 32.1 & 81 & 100 \\
\hline Kurang & 3 & 75.0 & 1 & 25.0 & 4 & 100 \\
\hline total & 58 & 68.2 & 27 & 31.8 & 85 & 100 \\
\hline
\end{tabular}

Nilai $\mathrm{p}=0.766$

\section{Hubungan Sikap Responden Dengan} Perilaku Pemberian ASI Ekslusif

Dari tabel diatas dapat dilihat dari 31 responden yang memiliki sikap tidak setujuh terhadap pemberian ASI Ekslusif pada bayinya terdapat 22(71.0\%) yang memberikan ASI Ekslusif pada bayinya dan $9(29.0 \%)$ yang tidak memberikan ASI Ekslusif pada bayinya. Dari 54 responden yang setujuh memberikan ASI Ekslusif sebanyak 36(66.7\%) yang memberikan ASI Ekslusif pada bayinya dan 18(33.3\%) yang tidak memberikan ASI Ekslusif pada bayinya.

Berdasarkan analisis statistic dengan Chi-Square diperoleh nilai $\mathrm{p}=0.682$ karena nilai $\mathrm{p}>0.05$ maka dapat dinyatakan bahwa tidak terdapat hubungan yang signifikan antara sikap responden terhadap ASI Ekslusif dengan perilaku pemberian ASI Ekslusif.

Tabel 11. Hubungan Sikap Responden Dengan Perilaku Pemberian ASI Ekslusif

\begin{tabular}{|c|c|c|c|c|c|c|}
\hline \multirow{3}{*}{ Sikap } & \multicolumn{6}{|c|}{ Perilaku Pemberian ASI Ekslusif } \\
\hline & \multicolumn{2}{|c|}{ Memberikan } & \multicolumn{2}{|c|}{ Tidak Memberikan } & \multicolumn{2}{|c|}{ Total } \\
\hline & $\mathbf{N}$ & $\%$ & $\mathbf{n}$ & $\%$ & $\mathbf{n}$ & $\%$ \\
\hline Setujuh & 36 & 66.7 & 18 & 33.3 & 54 & 100 \\
\hline Tidak Setujuh & 22 & 71.0 & 9 & 29.0 & 31 & 100 \\
\hline total & 58 & 68.2 & 27 & 31.8 & 85 & 100 \\
\hline
\end{tabular}

\section{Hubungan Dukungan Keluarga Responden Dengan Perilaku Pemberian ASI Ekslusif}

Dari tabel diatas dapat dilihat bahwa dari 21 responden yang tidak mendapatkan dukungan keluarga terhadap pemberian ASI Ekslusif terdapat 13(61.9\%) yang memberikan ASI Ekslusif dan hanya 8(38.1\%) yang tidak memberikan ASI Eklusif. Dari 64 responden yang mendapatkan dukungan keluarga terdapat
45(70.3\%) yang memberikan ASI Ekslusif dan $19(29.7 \%)$ yang tidak memberikan ASI Ekslusif.

Berdasarkan analisis statistic dengan Chi-Square diperoleh nilai $\mathrm{p}=0.473$ karena nilai $\mathrm{p}>0.05$ maka dapat dinyatakan bahwa tidak terdapat hubungan yang signifikan antara dukungan keluarga terhadap ASI Ekslusif dengan perilaku pemberian ASI Ekslusif.

Tabel 12. Hubungan Dukungan Keluarga Responden Dengan Perilaku Pemberian ASI Ekslusif

\begin{tabular}{|c|c|c|c|c|c|c|}
\hline \multirow{3}{*}{ Dukungan } & \multicolumn{6}{|c|}{ Perilaku Pemberian ASI Ekslusif } \\
\hline & \multicolumn{2}{|c|}{ Memberikan } & \multicolumn{2}{|c|}{ Tidak Memberikan } & \multicolumn{2}{|r|}{ Total } \\
\hline & $\mathbf{N}$ & $\%$ & $\mathbf{n}$ & $\%$ & $\mathbf{n}$ & $\%$ \\
\hline Mendukung & 45 & 70.3 & 19 & 29.7 & 64 & 100 \\
\hline Tidak Mendukung & 13 & 61.9 & 8 & 38.1 & 21 & 100 \\
\hline total & 58 & 68.2 & 27 & 31.8 & 85 & 100 \\
\hline \multicolumn{7}{|c|}{ Nilai $\mathrm{p}=0.473$} \\
\hline \multicolumn{7}{|c|}{$\begin{array}{l}\text { Tabel 13. Analisis statistic hubungan variable bebas dengan variable terikat menggunakan Uji Chi } \\
\text { Square pada tingkat keselahan }(\alpha) \text { sebesar } 5 \% \text {. }\end{array}$} \\
\hline No $\quad$ Variab & Bebas & Val & Terik & Nilai p & & Keterangan \\
\hline
\end{tabular}




\begin{tabular}{|c|c|c|c|c|}
\hline 1 & Umur & \multirow{6}{*}{$\begin{array}{l}\text { Perilaku Pemberian } \\
\text { ASI Ekslusif }\end{array}$} & 0.082 & Tidak ada hubungan \\
\hline 2 & Pendidikan & & 0.847 & Tidak ada hubungan \\
\hline 3 & Pekerjaan & & 0.159 & Tidak ada hubungan \\
\hline 4 & Pengetahuan & & 0.766 & Tidak ada hubungan \\
\hline 5 & Sikap & & 0.682 & Tidak ada hubungan \\
\hline 6 & Dukungan keluarga & & 0.473 & Tidak ada hubungan \\
\hline
\end{tabular}

\section{Analisis Multivariat}

Analisis multivariat yang diterapkan adalah analisis regresi logitik untuk menguji variable yang secara multivariate memiliki pengaruh yang sangat besar terhadap variable terikat. Analisis regresi logistic merupakan sala satu pendekatan model matematis yang digunakan untuk menganalisis hubungan beberapa variable bebas dengan variable terikat yang bersifat dikotomi atau biner, oleh karena itu analisis ini tepat untuk diterapkan dalam penelitian ini mengingat variable terikat penelitian ini bersifat dikotomi yaitu perilaku memberikan ASI Ekslusif dan tidak memberikan ASI Ekslusif.

Sebelum melakukan analisis mulivariat dengan regresi logistic terlebih dahulu melakukan regresi bivariat menggunakan uji regresi logistic sederhana. Seleksi bivariat melihat nilai $\mathrm{p}$ yang dihasilkan. Bila hasil bivariat menghasilkan nilai $\mathrm{p}<0.25$ maka variable tersebut masuk tahap multivariate.

Tabel 14. Analisa statistic hubungan variable bebas dengan variable terikat dengan menggunakan uji regresi logistic.

\begin{tabular}{|l|l|c|c|}
\hline No & \multicolumn{1}{|c|}{ Variabel bebas } & Nilai p & Keterangan \\
\hline 1 & Umur & 0.171 & Tidak lulus seleksi \\
\hline 2 & Pekerjaan & 0.360 & Tidak lulus seleksi \\
\hline
\end{tabular}

Dari tabel diatas dapat dilihat bahwa nilai $\mathrm{p}$ $>0.05$ maka variable tersebut dikeluarkan dari model uji Multivariat

\section{PEMBAHASAN}

\section{Karakteristik}

\section{Umur}

Umur responden yang terbanyak pada golongan umur tua yakni berkisar antara 31-45 Tahun (71.6\%) yang memberikan ASI Ekslusif pada bayinya. Berdasarka teori Health Belife Model bahwasanya umur seseorang termasuk salah satu faktor yang dapat mempengaruhi perilaku tertentu seseorang. Notoatmodjo (2003) yang mengemukakan bahwa umur merupakan lama hidup yang dihitung sejak dilahirkan, semakin bertambahnya umur seseorang semakin banyak pula daya tangkapnya. Seseorang dengan umur yang semakin berambah akan semakin baik dalam menentukan pilihan karena sudah banyak menerima informasi dari lingkungan sekitar,teman dan tetangga. Pernyataan ini menunjukan bahwa dengan umur responden yang semakin tua akan memahami bahwa betapa pentingnya ASI Ekslusif pada bayinya dan mereka akan berusaha agar selalu memberikan yang terbaik kepada bayinya. Dari hasil uji statistic didapatkan bahwa tidak ada hubungan yang signifikan antara umur responden dengan perilaku pemberian ASI Eklusif di Kel. Tabona Ternate.hal ini tidak sejalan dengan penelitian dari novira (2011) yang menjelaskan bahwa ada hubungan bermakna antara pengetahuan ibu tentang MP ASI dengan pemberian Makanan Pendamping ASI pada bayi usia 0-6 bulan di BPS Heni Suharni Desa Langensari Kecamatan Ungaran barat Kabupaten Semarang.

\section{Pendidikan}

Pendidikan responden yang terbanyak pada responden dengan pendidikan menegah Atas yakni 27 dan dari ketiga kategori pendidikan mulai dari tingkat Sekolah Dasar (SD) hingga Perguan Tinggi (PT) rata - rata memberikan ASI Ekslusif pada Bayinya. Dari hasil uji statistic didapatkan bahwa tidak ada hubungan yang signifikan antara pendidikan responden dengan perilaku pemberian ASI Ekslusif di Kel. Tabona Ternate.

\section{Pekerjaan}

Dari hasil penelitian didapatkan responden yang memiliki pekerjaan sebanyak 41(48.2\%)dan yang memberikan ASI Ekslusif pada bayinya sebanyak 31(75.6\%) sisanya sebanyak $10(24.4 \%)$ yang tidak memberikan ASI Ekslusif pada bayinya. 
Responden yang tidak memiliki pekerjaan sebanyak 44(51.8\%) dan yang memberikan ASI Ekslusif pada bayinya sebanyak $27(61.4 \%)$ sisanya sebasar $17(38.6 \%)$ yang tidak memberikan ASI Ekslusif pada bayinya. Dari hasil uji statistic didapatkan bahwa tidak ada hubungan yang signifikan antara pekerjaan responden dengan perilaku pemberian ASI Ekslusif di Kel. Tabona Ternate. Walaupun hasil uji statistic menunjukan tidak ada hubungan antara pekerjaan dengan perilaku pemberian ASI Eklusif namun dari data dapat dilihat bahwa yang lebih banyak memberikan ASI Ekslusif pada bayinya adalah responden yang memiliki pekerjaan. Sesuai dengan definisi pekerjaan yaitu kegiatan yang harus dilakukan untuk menunjang kehidupanya dan kehidupan keluarganya. Pekerjaan ibu juga diperkirakan dapat mempengaruhi pengetahuan dan kesempatan ibu dalam memberikan ASI Ekslusif, dibandingkan dengan pengetahuan ibu yang tidak bekerja.

4. Pengetahuan Responden Terhadap ASI Ekslusif

Dari hasil penelitian didapatkan responden yang memiliki pengetahuan tentang ASI Ekslusif kategori baik sebanyak 81(95.3\%), yang memberikan ASI Eklusif pada bayinya sebesar $55(67.9 \%)$ dan yang tidak memberikan ASI Ekslusif sebesar 26(32.1\%). Responden yang memiliki pengetahuan tentang ASI Ekslusif dengan kategori kurang hanya 4(4.7\%) dan hanya $1(4.7 \%)$ yang tidak memberikan ASI Ekslusif pada bayinya.

Dari hasil uji statistic didapatkan bahwa tidak ada hubungan yang signifikan antara pengetahuan responden terhadap ASI Ekslusif dengan perilaku pemberian ASI Ekslusif di Kel. Tabona Ternate. Namun dari data dapat dilihat bahwa dengan pengetahuan kategori baik maka angka pemberia ASI Ekslusifpun lebih banyak.

5. Sikap Responden terhadap Pemberian ASI Ekslusif

Dari hasil penelitian didapatkan jumlah responden yang memiliki sikap mendukung terhadap pemberian ASI Ekslusif sebesar $54(63.5 \%)$ dan yang memberikan ASI Ekslusif pada bayinya sebanyak 36(66.7\%) lebih besar dibanding yang tidak memberikan ASI Eklusif pada bayinya. Jumlah responden yang tidak mendukung pemberian ASI Ekslusif sebesar 31(35.5\%) dan yang memberikan ASI Ekslusif sebesar 22(71.0\%) lebih banyak dibandingkan dengan yang tidak memberikan ASI Ekslusif 9(29.0\%).

Dari hasil uji statistic didapatkan bahwa tidak ada hubungan yang signifikan antara pengetahuan responden tentang ASI Ekslusif dengan perilaku pemberian ASI Ekslusif di Kel. Tabona Ternate.

\section{Dukungan Keluarga Terhadap Pemberian} ASI Ekslusif

Dari hasil penelitian didapatkan bahwa responden yang mendapatkan dukungan dari keluarga cukup besar angkanya yakni 64(73.3\%) dan yang memberikan ASI Ekslusif pada bayinya sebesar 45(70.3\%) lebih besar dibandingkan dengan yang tidak memberikan ASI Ekslusif pada bayinya yakni sebesar 19(29.7\%). Sedangkan responden yang tidak mendapatkan dukungan dari keluarga mengenai pemberian ASI Ekslusif sebanyak 21(24.7\%) dan yang memberikan ASI Ekslusif pada bayinya sebanyak 13(61.9\%) lebih banyak dibandingkan dengan yang tidak memberikan ASI Ekslusif yakni sebesar8(38.1\%).

Dari hasil uji statistic didapatkan bahwa tidak ada hubungan yang signifikan antara dukungan keluarga terhadap pemberian ASI Ekslusif dengan perilaku pemberian ASI Ekslusif di Kel. Tabona Ternate.

\section{KESIMPULAN DAN SARAN}

\section{Kesimpulan}

1. Pengetahuan responden terbanyak pada kategori pengetahuan baik 81(95.3\%) dan perilaku pemberian ASI Ekslusif yang tertinggi terdapat pada responden dengan kategori pengetahuan baik yakni $55(67.9 \%)$.

2. Sikap responden terhadap pemberian ASI Ekslusif menunjukan banyak respondeng yang mendukung 54(63.5\%) dan 31(36.5\%) yang tidak mendukung pemberian ASI Ekslusif pada bayinya.

3. Dukungan Keluarga tehadap responden dalam pemberian ASI Ekslusif yang terbanyak yakni mendukung responden dalam pemberian Asi Ekslusif pada bayinya $64(75.3 \%)$ dan 21(24.7\%) yang tidak mendukung.

4. Uji statistic menunjukan bahwa tidak ada hubungan yang signifikan antara variable bebas dengan variable terikat.

Saran 
Walaupun dari hasil uji statistic menunjukan bahwa tidak ada hubungan antara variable terikat dengan variable bebas pada penelitian ini, namun dapat dilihat bahwa responden dengan pengetahuan yang baik maka perilaku pemberian ASI Ekslusif lebih banyak dibandingkan dengan yang memiliki pengetahuan rendah artinya masyarakat Tabona harus selalu diberikan pengetahuan tentang manfaat ASI Ekslusif agar masyarakat memberikan ASI Ekslusif pada bayinya.

\section{DAFTAR PUSTAKA}

Admin, Pekan ASI Dunia Dukung Ibu Agar Menyusui Secara Eksklusif, http//www.Dunia Ibu. last update, 2008 (diakses 11 Mei 2012).

Burhan Bungin,2006, Metodologi Penelitian Kuantitatif,Kencana, Jakarta.

Depkes RI, 1992, Manajemen Laktasi, Dit, Bina Gizi Masyarakat, Jakarta. 2001, Manajemen Laktasi, Dit, Bina Gizi Masyarakat, Jakarta.

Dini Saraswati S, Pemberian ASI Eksklusif dipengaruhi Pengetahuan dan Pekerjaan, http/www.comment-page-1 last update 2008 (diakses 12 Juni 2012).

Dahlan Sopiyudin,2011, Statistik Untuk Kedokteran dan Kesehatan,Salemba Medika, Jakarta.

Handayani, 2008, Pemberian ASI Eksklusif di Pengaruhi Pengetahuan dan Pekerjaan, http/www.com-page-1 last update (diaskes 12 Juni 2012).

M. Widad, Cuti Melahirkan dan Memberi ASI Eksklusif , http//www.WHO int/Sentral laktasi, mutiply, com last update, 2007 (diakses 20 Januari 2012).

Notoatmadjo S, 1997, Ilmu Kesehatan Masyarakat, Rineka Cipta, Jakarta.

S, 1993, Pengantar Pendidikan Kesehatan dan Ilmu Perilaku Kesehatan, Andi Offset, Jokjakarta.

S, 2002, Metodologi Penelitian Kesehatan, Rineka Cipta, Jakarta.

Nazir Moh,2003,Metode Penelitian, Ghalia Indonesia, Jakarta.

Prof Dr. Solihin Putjiadi, DSAK, Ilmu Gizi Klinik Pada Anak, Penerbit FKUI, Jakarta.

Profil Dinas Kesehatan Kota, 2007

Prof Dr. H. M. Alimin Maidin, MPH, 2007, Diktat Dasar-Dasar Administrasi Kesehatan, Promosi Kesehatan Masyarakat Indonesia.

Rachmawati dan Rienkuantri, ASI Eksklusif Demi Sang Anak, http//www.dunia go.id, last update, 2007 (diakses 12 Mei 2012).

Roesli U, 2000, Mengenal ASI Eksklusif, Trubus Agriwidya, Jakarta.

Robert L. Mathis dan John H, Jackson, 2001, Manajemen Sumber Daya Manusia, PT. Salemba empat Patria.

Ridwan Amirudin, WHO Merekomendasi Untuk Hanya Pemberian ASI Sampai Bayi Berusia 4-6 Bulan, (Siaran Pers Unicef, 2004) from http//www. litbang. Go id, last update, 2007 (diakses 03 Januari 2012).

Riwidikdo, 2010, Statistik Kesehatan,Mitra Cendikia,Jogjakarta.

Suririna, Air Susu Ibu (ASI) Memberi Keuntungan Ganda Untuk Ibu dan Bayi. http//www.di gilid.litbang depkes, po.id, last update:2004 (diakses tanggal 5 Mei 2012).

Sugiono,2009,Metode Penelitian Kuantitatif Kualitatif dan R\&D,Alfabeta,Bandung.

Saryono, 2008,Metodologi Penelitian Kesehatan,Mitra Cendikia,Jogjakarta.

USU, Pemberian ASI Di Pengaruhi Oleh Faktor-Faktor Sosial, Psikologis Fisik Ibu, Kurangnya Petugas Kesehatan dan Gencarnya Susu Formula, http//www. Library, ac.id / Arifin Dowaload, last update, 2004 (diakses 24 Maret 2012).

Watik Rahayu, Hubungan Tingkat Pengetahuan Ibu Tentang ASI Eksklusif dengan Pemberian ASI Eksklusif pada bayi/http.www.indo global.com.last update, 2006 (diakses 28 Februari 2012). 
